\title{
Do Restrained Eaters Show Attention Toward or Away From Food, Shape and Weight Stimuli?
}

Citation for published version (APA):

Boon, B. J. F., Vogelzang, L., \& Jansen, A. T. M. (2000). Do Restrained Eaters Show Attention Toward or Away From Food, Shape and Weight Stimuli? European Eating Disorders Review, 8, 8-1. https://doi.org/10.1002/(SICl)1099-0968(200002)8:1<51::AID-ERV306>3.0.CO;2-E

Document status and date:

Published: 01/01/2000

DOI:

10.1002/(SICI)1099-0968(200002)8:1<51::AID-ERV306>3.0.CO;2-E

Document Version:

Publisher's PDF, also known as Version of record

Document license:

Taverne

Please check the document version of this publication:

- A submitted manuscript is the version of the article upon submission and before peer-review. There can be important differences between the submitted version and the official published version of record.

People interested in the research are advised to contact the author for the final version of the publication, or visit the DOI to the publisher's website.

- The final author version and the galley proof are versions of the publication after peer review.

- The final published version features the final layout of the paper including the volume, issue and page numbers.

Link to publication

\footnotetext{
General rights Owners
rights.

- You may freely distribute the URL identifying the publication in the public portal. please follow below link for the End User Agreement:

www.umlib.nl/taverne-license

Take down policy

If you believe that this document breaches copyright please contact us at:

repository@maastrichtuniversity.nl

providing details and we will investigate your claim.
}

Copyright and moral rights for the publications made accessible in the public portal are retained by the authors and/or other copyright owners and it is a condition of accessing publications that users recognise and abide by the legal requirements associated with these

- Users may download and print one copy of any publication from the public portal for the purpose of private study or research.

- You may not further distribute the material or use it for any profit-making activity or commercial gain

If the publication is distributed under the terms of Article $25 \mathrm{fa}$ of the Dutch Copyright Act, indicated by the "Taverne" license above, 


\title{
Paper
}

\section{Do Restrained Eaters Show Attention Toward or Away From Food, Shape and Weight Stimuli?}

\author{
Brigitte Boon $^{1 *}$, Leo Vogelzang ${ }^{2}$ and Anita Jansen ${ }^{1}$ \\ ${ }^{1}$ Maastricht University, Department of Psychology, PO Box 616, \\ 6200 MD Maastricht, The Netherlands \\ ${ }^{2}$ Utrecht University, Department of Social and Organizational Psychology, \\ PO Box 80140, 3508 TC Utrecht, The Netherlands
}

The present study was designed to examine whether the frequently found prolonged colour naming of food words in Stroop tasks in people who restrain their food intake is due to hyperattention to or avoidance of these food words. MacLeod's visual attention (or dot probe) paradigm (MacLeod et al., 1986) was used, as well as a word recognition task. Food, weight/shape and neutral words were presented. Fifty-nine women, classified as restrained or unrestrained eaters, participated in both tasks. The visual attention task revealed neither attention nor avoidance of food and weight/ shape stimuli. In the recognition task, however, restrained subjects were found to need less time for recognizing food words than neutral words. For unrestrained eaters, the response times for food and neutral words were the same. The results in this study, may be explained by Wegner's Ironic Process Theory (Wegner, 1994). Wegner argues that, in order to avoid certain thought contents, an individual needs to attend to those contents. For the restrained eater this might mean that she first shifts attention towards the food words in the dot probe task in order to subsequently avoid them, which might explain the zero net effect. Indirect support for the idea that restrained eaters needed to attend the food words in order to avoid them, is found in the results of the recognition task: restrained subjects needed less time to recognize food stimuli than neutral stimuli. Copyright (C) 2000 John Wiley $\mathcal{E}$ Sons, Ltd and Eating Disorders Association.

Keywords: visual attention paradigm; restrained eating; attentional bias; cognitive avoidance

\footnotetext{
*Correspondence to: Dr B. Boon, Maastricht University, Faculty of Psychology, Department of Experimental Psychology, PO Box 616, 6200 MD Maastricht, The Netherlands. Tel: +31-43-3881948. E-mail: B.Boon@psychology.unimaas.nl
} 


\section{INTRODUCTION}

Attempts to lose weight or to restrain food intake are supposed to lead to hyperattention for food stimuli. Indeed, observational and self-report studies show that subjects on weight-reducing diets become obsessed and preoccupied with food and eating (Keys et al., 1950; Warren and Cooper, 1988) and experiments with the modified Stroop task repeatedly showed prolonged colour naming latency to food stimuli in fasting subjects, restrained eaters and eating disordered patients (e.g. see Overduin et al., 1995). The prolonged colour naming latency for food words in subjects who restrain their food intake is generally reported as evidence for selective hyperattention to the food cues. It is argued that restrained subjects attend to the word content and therefore show larger interference effects to the food stimuli. However, all one can tell from the prolonged colour naming latencies for food words is that restrained subjects do not process the colour of the food words efficiently, which does not mean that they are attending to the word content. A slowing of colour naming might be caused by attentional avoidance of the food words, e.g. by looking away or closing one's eyes (MacLeod, 1997, personal communication; MacLeod et al., 1986; MacLeod and Mathews, 1988). It has indeed been demonstrated that the intention to avoid processing certain word contents leads to prolonged colour naming for those words; normal subjects who were instructed to suppress all thoughts about numbers showed higher response times for colour naming number words than for non-number control words in a Stroop test (Lavy and van den Hout, 1994). Considering the hypothesis of Herman and Polivy (1993) that 'dieters stand a better chance of adhering to their diets if they can manage to avoid thinking about food' (p.479), one might hypothesize that a cognitive focus on food cues is exactly what dieters try to avoid.

The present study was designed to find out whether the prolonged colournaming latencies for food words in restrained eaters reflect an attentional orientation towards or away from the food stimuli. Because restrained eaters also show slower colour naming for shape and weight (e.g. Ben-Tovim and Walker, 1991; Fairburn et al., 1991; Ogden and Greville, 1993), it was decided to test also whether the colour-naming latencies for shape and weight words reflect attention for or avoidance of the shape/weight stimuli.

\section{METHOD}

Fifty-nine women participated in the experiment. They were classified as restrained or unrestrained eaters according to the median split (13) of scores on the Restraint Scale (RS; Herman et al., 1978), meaning that subjects scoring 13 or less were classified as unrestrained eaters $(n=30)$ and subjects 
scoring 14 or more as restrained eaters $(n=29)$. Mean restraint scores were $17.9( \pm 3.5)$ for the restrained eaters and $8.6( \pm 3.3)$ for the unrestrained eaters. There were no group differences in subjective hunger at the start of the experiment. MacLeod's dot probe paradigm (Macleod et al., 1986) was used to test whether restrained subjects show an attentional orientation towards or away from the target stimuli. The task ran under Windows 95 on a standard IBM personal computer with a 15-inch SVGA colour monitor. A single digit number (between 1 and 9) was presented centrally on the screen and the subject was instructed to read that number aloud, to ensure that she would fixate on the middle of the screen. Then a word pair (a target and a neutral word) was presented briefly $(500 \mathrm{~ms})$ in the middle of the screen, one word $3 \mathrm{~cm}$ above the other (each word $1.5 \mathrm{~cm}$ above or below the fixation point). The target words consisted of 24 food words and 24 weight/shape words, the neutral words consisted of 24 home related and 24 office related words. ${ }^{1}$ The target word in each pair appeared with equal probability above or below the fixation point. The words were followed by a probe (arrow) which appeared with equal probability in the spatial location of either one of the words, immediately after the disappearance of the word. Subjects pressed the right or left button of a mouse, immediately when the probe was detected (they were instructed to respond as quickly as possible to the probe; pressing right when the arrow pointed to the right, pressing left when it pointed to the left). After pressing, the probe disappeared. Ten practice trials were run, followed by 48 experimental trials. For each probe the detection time (discrimination latency; $1 \mathrm{~ms}$ accuracy) was recorded. Shorter discrimination latencies to target words, i.e. a faster response to the probe when it is in the same location as the target words than when it is in the same location as the neutral words, means enhanced attention for the target words. Prolonged discrimination latencies to target words, i.e. a slower response to the probe when it is in the same location as the target words than when it is in the same location as the neutral words, means avoidance of the target words.

It was assumed that selective attention for stimuli would also be reflected in a better recognition of those stimuli. After the probe task, subjects were again presented with the target and neutral words as well as with new words. The words were presented one by one in the centre of the screen and disappeared when the subject clicked the mouse to indicate whether or not she recognized the word (the left button was the 'yes-button', the right button was the 'no button'). Latency times were recorded for each word and the number of errors was registered.

\footnotetext{
${ }^{1}$ Since thematic (un)relatedness of stimuli can affect reaction times (Mogg et al., 1991), the shape/weight words were paired with office-related words and the food words with home-related words.
} 
Table 1. Mean reaction times on the visual attention task for target + and targettrials,* separate for food and weight/shape words and for both words combined

\begin{tabular}{|c|c|c|c|c|c|}
\hline & & \multicolumn{2}{|c|}{ Restrained eaters $(n=29)$} & \multicolumn{2}{|c|}{ Unrestrained eaters $(n=30)$} \\
\hline & & M & SD & M & SD \\
\hline \multirow[t]{3}{*}{ Target +} & Both words & 544.6 & 85.5 & 524.1 & 67.4 \\
\hline & Food & 545.2 & 90.8 & 521.8 & 66.3 \\
\hline & Weight/shape & 543.9 & 85.2 & 526.5 & 71.7 \\
\hline \multirow[t]{3}{*}{ Target- } & Both words & 543.9 & 76.3 & 524.7 & 66.8 \\
\hline & Food & 541.8 & 79.2 & 527.1 & 74.6 \\
\hline & Weight/shape & 546.0 & 79.3 & 522.4 & 63.8 \\
\hline
\end{tabular}

*The target+ score indicates the latencies for the probe that was presented in the same position as the target word; the target - score shows the latencies for probes that appeared in the same position as the neutral word. If subjects avoid the target words, the target+ score should be higher than the target- score; selective attention for the target words should be characterized by lower target+ scores than target- scores.

\section{RESULTS}

\section{Visual attention task}

Errors, latencies of less than $200 \mathrm{~ms}$ and latencies greater than $1500 \mathrm{~ms}$ were removed. Mean latencies were then calculated for each subject under each of four possible conditions, representing all possible combinations of type of target-word (food or shape/weight) and the location of the probe (near to or distant from the stimulus word) (see Table 1). A MANOVA with Group (restrained versus unrestrained; between subjects) and Probe Position (target+ versus target-; within subjects) as factors and mean latencies for the food word trials as the dependent variable, showed neither main effects (Group $F(1,58)=0.97$, n.s.; Probe Position $F(1,58)=0.03$, n.s.), nor a Group $\times$ Probe Position interaction $(F(1,58)=0.64$, n.s. $)$. The same was true for the weight/shape word trials (Group $F(1,58)=1.20$, n.s.; Probe Position $F(1,58)=0.04$, n.s.; Group $\times$ Probe Position $F(1,58)=0.36$, n.s. $)$. Thus no evidence was found for selective attention to or cognitive avoidance of foodand shape/weight-related stimuli in high and low restrained eaters.

\section{Recognition task}

Response times smaller than $200 \mathrm{~ms}$ and greater than $3000 \mathrm{~ms}$ were removed. Mean number of errors and mean latencies (errors excluded) were calculated for the shape/weight words, the food words and both categories of neutral words. A MANOVA with Group (restrained versus unrestrained) and Word Type (target versus neutral) as factors and the number of errors as the dependent variable, 
Table 2. Mean number of errors and mean reaction times on the recognition task, separate for food and weight/shape words and for both words combined

\begin{tabular}{|c|c|c|c|c|c|}
\hline & & \multicolumn{2}{|c|}{ Restrained eaters $(n=23)$} & \multicolumn{2}{|c|}{ Unrestrained eaters $(n=26)$} \\
\hline & & M & SD & M & SD \\
\hline \multirow[t]{6}{*}{ Errors } & Target words & 22.9 & 9.6 & 25.8 & 12.3 \\
\hline & Food & 13.1 & 5.4 & 13.8 & 6.5 \\
\hline & Weight/shape & 9.8 & 5.1 & 12.0 & 6.3 \\
\hline & Neutral words & 31.2 & 11.9 & 32.1 & 11.0 \\
\hline & Office & 14.6 & 6.3 & 17.4 & 5.7 \\
\hline & Home & 16.6 & 6.0 & 14.6 & 6.0 \\
\hline \multirow[t]{6}{*}{ Reaction times } & Target words & 965.6 & 131.0 & 932.1 & 143.7 \\
\hline & Food & 965.6 & 154.9 & 944.5 & 163.9 \\
\hline & Weight/shape & 959.4 & 129.4 & 908.0 & 178.4 \\
\hline & Neutral words & 1055.4 & 193.9 & 974.6 & 143.2 \\
\hline & Office & 996.0 & 167.7 & 974.4 & 239.9 \\
\hline & Home & 1089.7 & 253.8 & 958.9 & 189.1 \\
\hline
\end{tabular}

showed a main effect for Word Type $(F(1,57)=1.92$, $p=0.000)$. Subjects made more mistakes in recognizing the neutral than the target words. Closer inspection of the data shows that the effect occurred for both categories of target words, as compared to their neutral words: shape/weight words $(F(1,57)=33.1, p=0.000)$ and food words $(F(1,57)=5.4, p=0.02)$. Furthermore, for the shape/weight words a main effect for group was revealed $(F(1,57)=3.9, p=0.05)$. Restrained eaters made fewer errors than unrestrained eaters. No interaction effect emerged. A MANOVA with response times as the dependent variable showed a main effect for Word Type $(F(1,47)=7.7$, $p=0.01)$, indicating that subjects needed more time to recognize neutral words than stimulus words. No main effect for Group nor a Group $\times$ Word Type interaction emerged. The main effect for Word Type occurred for both types of words, although only marginally for the shape/weight words (Shape/ weight words $F(1,53)=3.4, p=0.07$; Food words $F(1,48)=5.6, p=0.02$ ). For the food words, also a marginally significant Group $\times$ Word Type interaction emerged $(F(1,48)=3.5, p=0.066)$. This interaction reveals that the unrestrained eaters (although faster than the restrained eaters) show about the same latencies for both food and neutral words, whereas the restrained eaters respond faster to the food words than to the neutral words.

\section{DISCUSSION}

In the present study it was examined whether restrained eaters' prolonged colour-naming latencies for food words in the Stroop task reflect an 
attentional orientation towards or away from the food words. Response times in the probe task showed neither selective attention nor cognitive avoidance of target stimuli in restrained eaters. In the recognition task, however, all subjects were better and faster in the recognition of target words than neutral words. The marginally significant Restraint $\times$ Word Type interaction shows that, with regard to food words only, restrained eaters recognized food words faster than neutral words, this difference was not found in unrestrained eaters.

It is remarkable that the probe task data do not support the idea that restrained eaters selectively attend to food stimuli, a finding which has repeatedly been documented by means of the modified Stroop test. The dot probe paradigm has been repeatedly shown to be sensitive to selective attention in anxiety patients (MacLeod et al., 1986; Macleod and Mathews, 1988; Broadbent and Broadbent, 1988; Mogg et al., 1992). Why did we not find hyperattention or avoidance? A first explanation might be that the present subject sample was not a clinical group. The dot probe paradigm may not be sensitive enough for normal restrained eaters, it might be a rewarding enterprise to replicate the study with eating disordered patients. Recently, for example, the visual attention test was used to assess attention toward negatively and positively valenced body shape-related words. Eating disordered subjects were found to direct attention away from positive shape words and toward negative shape words, whereas restrained subjects showed no attentional bias for the shape words. Food words, however, were not included in the experiment (Rieger et al., 1998). Secondly, Wegner's Ironic Process Theory states that, in order to avoid certain thought contents, an individual needs to attend those contents (Lavy and Van den Hout, 1994; Wegner, 1994). For the restrained eater this might mean that she needs to shift attention towards the food word in the dot probe task in order to subsequently avoid it. Semantic priming is at its strongest at about $500 \mathrm{~ms}$ after a prime (Hermans and Eelen, 1998); at that moment the meaning of the word is fully understood, and avoiding tendencies should start. The implication presumably is that, in the present visual attention paradigm, some subjects avoid and others attend the target words, which might explain why neither selective attention, nor cognitive avoidance could be detected in the present study. Indirect support for the idea that restrained eaters needed to attend the food words in order to avoid them, is found in the results of the recognition task: restrained subjects needed less time to recognize food stimuli than neutral stimuli. In order to determine the exact attention curve of restrained eaters, it would be rewarding to examine eye movements of restrained and unrestrained eaters during the presentation of target and neutral stimuli. It might be expected that restrained eaters show more approach as well as avoidance movements (more saccades between target and neutral stimuli) than unrestrained eaters. Only research can tell. 


\section{ACKNOWLEDGEMENTS}

The authors thank Colin MacLeod for his helpful suggestions regarding the programming of the paradigm and the design of the study. Thanks are also due to Marjon de Zwart for her advice concerning the programming and to Richta IJntema for her help with collecting the data.

\section{REFERENCES}

BEN-TOVIM, D. I. and Walker, M. K. (1991). Further evidence for the Stroop test as a quantitative measure of psychopathology in eating disorders. International Journal of Eating Disorders, 10, 609-613.

BROADBENT, D. and Broadbent, M. (1988). Anxiety and attentional bias: State and trait. Cognition and Emotion, 2, 165-183.

FAIRBURN, C. G., Cooper, P. J., Cooper, M. J., McKenna, F. P. and Anastasiades, P. (1991). Selective information processing in bulimia nervosa. International Journal of Eating Disorders, 10, 415-422.

HERMAN, C. P. and Polivy, J. (1993). Mental control of eating: Excitatory and inhibitory food thoughts. In: Handbook of Mental Control (eds D. M. Wegner and J. W. Pennebaker). Englewood Cliffs: Prentice Hall, Inc., pp. 491-505.

HERMAN, C. P., Polivy, J., Pliner, P., Threlkeld, J. and Munic, D. (1978). Distractibility in dieters and nondieters: An alternative view of 'externality'. Journal of Personality and Social Psychology, 36, 536-548.

HERMANS, D. and Eelen, P. (1998). Eye movement registration as a continuous measure of attention deployment: data from a group of spider anxious students. Paper presented at the Meeting of the FWO Research Community on the Acquisition, Representation and Activation of Affect, Leuven, Belgium, 5-6 March 1998.

KEYS, A., Brozek, J., Henschel, A., Mickelsen, O. and Taylor, H. L. (1950). The Biology of Human Starvation. Minneapolis, MN: University of Minnesota Press.

LAVY, E. H. and Van den Hout (1994). Cognitive avoidance and attentional bias: Causal relationships. Cognitive Therapy and Research, 18, 179-191.

MACLEOD, C. and Mathews, A. (1988). Anxiety and the allocation of attention to threat. The Quarterly Journal of Experimental Psychology, 40, 653-670.

MACLEOD, C., Mathews, A. and Tata, P. (1986). Attentional bias in emotional disorders. Journal of Abnormal Psychology, 95, 15-20.

MOGG, K., Mathews, A. and Eysenck, M. (1992). Attentional bias to threat in clinical anxiety states. Cognition and Emotion, 6, 149-159.

OGDEN, J. and Greville, L. (1993). Cognitive changes to preloading in restrained and unrestrained eaters as measured by the Stroop task. International Journal of Eating Disorders, 14, 185-195.

OVERDUIN, J., Jansen, A. and Louwerse, E. (1995). Stroop interference and food intake. International Journal of Eating Disorders, 18, 227-285. 
RIEGER, E., Schotte, D. E., Touyz, S. W., Beumont, P. J. V., Griffiths, R. and Russel, J. (1998). Attentional biases in eating disorders: A visual probe detection procedure. International Journal of Eating Disorders, 23, 199-205.

WARREN, C. and Cooper, P. J. (1988). Psychological effects of dieting. British Journal of Clinical Psychology, 27, 269-270.

WEGNER, D. M. (1994). Ironic processes of mental control. Psychological Review, $101,34-52$. 